\title{
The Neolithic in Almería: the valley of the Almanzora river and Vera basin
}

\author{
María Dolores Cámalich1, Dimas Martín-Socas², Pedro González³, \\ Antonio Goñi ${ }^{4}$, Áquede Rodríguez 5 \\ 1 Departamento de Prehistoria, Antropología e Historia Antigua. Universidad de La Laguna \\ dmassieu@ull.es \\ 2 Departamento de Prehistoria, Antropología e Historia Antigua. Universidad de La Laguna \\ dsocas@ull.es \\ 3 Departamento de Ciencias Históricas. Universidad de Las Palmas de Gran Canaria \\ pgonzalez@dch.ulpgc.es \\ 4 Departamento de Prehistoria, Antropología e Historia Antigua. Universidad de La Laguna \\ 5 Departamento de Ciencias Históricas. Universidad de Las Palmas de Gran Canaria \\ arodriguez@dch.ulpgc.es
}

\begin{abstract}
The valley of the Almanzora River and Vera Basin (Almería) shows an intense dynamics of occupation in Prehistory, particularly between the Early Neolithic and the Late Bronze Age. Several factors, such as the recurrent associations between diverse productions - including the presence of cardial-impressed pots in Cabecicos Negros (Vera) - and the distinctive characteristics of the type of occupation, indicate that the oldest phase of occupation took place during the Andalusian Early Neolithic. The socio-economic pattern is defined both by the exploitation of numerous resources in an area of variable size, and by the temporary occupation of settlements, with seasonal or periodical variations. This constant mobility was aimed at obtaining different subsistence goods, as well as obtaining and/or transforming primary resources for manufacturing crafts and exchanging excess production with communities in the same area or from other regions.
\end{abstract}

IZVLEČEK - Dolina reke Almanzora in kotlina Vera (Almería) kažeta veliko dinamiko poselitve vprazgodovini, še posebno med zgodnjim neolitikom in pozno bronasto dobo. Medsebojna povezanost različnih produkcij - vključno z navzočnostjo impresso-cardium keramike v Cabecicos Negros (Vera) - in jasne značilnosti tipa naselitve kažejo, da je najstarejša faza poselitve potekala v času andaluzijskega zgodnjega neolitika. Za družbeno-gospodarski vzorec sta značilna izkoriščanje številnih virov na različno velikih površinah ter začasna (sezonska oziroma periodična) poselitev naselbin. Namen stalne mobilnosti je bil pridobiti različne dobrine za preživetje in pridobiti oziroma predelati primarne vire za proizvodnjo izdelkov ter menjevanje viškov proizvodnje s skupnostmi na istem območju ali s skupnostmi iz drugih regij.

KEY WORDS - Andalusia; Neolithic; social interactions; palaeoeconomy

When approaching the analysis of the dynamics of social formations in the context of Recent Prehistory in the so-called lowlands of southeast Iberia, one of the first problems is the tradition of the studies of $\mathrm{E}$. and L. Siret and P. Flores and of the archaeological data recovered at the end of the $19^{\text {th }}$ and beginnings of the $20^{\text {th }}$ century. This documentation constitutes the fundamental empirical support for studies of set- tlement patterns in the region. It was basically interpreted from a traditional point of view as the result of the maritime movements of Mediterranean and other settlers.

We consider that the analysis of P. Bosch Gimpera (1932; 1944; 1965; 1969) in the 30's was the first important systematic study of the Neolithic and early 
Chalcolithic societies in the region. He introduced concept of genesis of two communities in Western Andalusia - Cultura de las Cuevas, with a wide influence in the peninsular territory, and Cultura de Almeria, restricted to the southeast, where the main centre was located. Within the five phases into which he divided the evolution of this culture, the first phase was defined by the social formations of the Final Neolithic, with its North African origin. The appearance of metallurgy was closely connected with Cultura de los Millares and its origin in the peninsular Neo-Eneolithic.

Nevertheless, as determining a period depends on the presence or absence of metals, the present discussion will focus on whether the Cultura de Almería corresponds to the last Neolithic phases societies or to the first Chalcolithic ones. In fact, throughout almost the whole of the $20^{\text {th }}$ century, investigations were focused on explaining how to access this technological innovation, which was considered as the impulse for the process of complexity and hierarchy in these societies. In the area of the Cultura de $\mathrm{El} \mathrm{Ar}$ gar there is an example of the climax of this process.

The resolution of this problem is imposed by each researcher's interpretation. If the pattern is diffusionism and colonialism, the Cultura de Almería will be considered as representative of the Ancient Chalcolithic; whereas, if the proposed pattern is an evolutionistlineal one, it will be identified as a Neo-Eneolithic culture. And both of these interpretation patterns use almost exclusively the same empirical base: the archaeological evidence unearthed by E. and L. Siret.

From the 80's, new theoretical and methodological patterns replaced diffusionism. Approaches were focused on establishing which factors played a role in the configuration of such a complex society of the Southeast region beginning in the middle of the third millennium BC.

Therefore, there are three initial and closely interrelated problems to solve:

- The origin and the causes of the impulse for agricultural colonisation in the lowlands of Almería;

- The origins of metallurgy, their internal dynamics and their consequences through the development of each prehistoric period and;

- The importance of this southeast area in this whole transformation.

To solve these initial problems and, mainly that of agricultural colonisation, environmental characteri- stics have been taken as a first consideration. Traditionally, it was accepted that the environment had very similar characteristics to that of the present: an arid or semi-arid climate, with a deforested landscape and a very active erosive action (Gilman and Thornes 1985). Within this general framework, some authors have adopted an intermediate position. They agree with the existence of small oscillations, with a small increment in humidity during the second millennium, coinciding with the development of the Bronze Age. (Walker 1985; 1986; Chapman 1991, although this author in previous publications, 1978 and 1984, has defended the absence of significant climatic changes).

Lately, due to the available paleo-ecological evidence for this region, the situation has changed. The existence of a more humid climate during the Neolithic and the Copper Ages, with a vegetation climax quite well conserved during the Neolithic that would begin to suffer an important deterioration starting from advanced moments of the Copper Age (the period between the third to the second millennium $\mathrm{BC}$ ) has now been highlighted. On the other hand, the presence of water courses was documented by the identification of ripisylvae species in settlements dating to the third millennium BC, like El Puente de Santa Bárbara (Huércal-Overa) and Los Millares (Santa Fé de Mondújar) (Rodríguez Ariza 1992; 1996; Pantaleon Cano et al. 1996; Yll et al. 1995; Cámalich Massieu and Martín Socas (drt.) 1999).

Nevertheless, we will defend different models for explaining at which moment the occupation takes place, as well as the interpretation of the strategies developed by these societies in the first periods of the Recent Prehistory of the peninsular Southeast. As we consider agricultural activity a priority factor in a subsistence lifestyle, the settlement choice will depend on soil and/or water resources. Thus a settlement and exploitation pattern of the territory focuses on the growing complexity of these social formations, starting from agricultural production or control of water resources.

On the other hand, the appropriate conditions for early agricultural colonisation in such a hard environment did not exist because of the absence of indispensable technological support. It is the reason this occupation was dated as subsequent to that of the more humid inland areas, as well as the western lands of Granada and Málaga (Chapman 1978; 1991). Consequently, the occupation of these lowlands of the peninsular Southeast took place at the 
end of the Neolithic. The Cultura de Almeria has been again representative in this area of this chronological and cultural period, as the process of organizational complexity begins, coinciding in time with the first development of metallurgical activity.

Furthermore, to understand the surge of global change of third millenium social formations, most researchers have interpreted southeast Iberia as one of the central areas of activity. The representative settlements at Garcél and Purchena and the Cantoria necropolis of the Late Neolithic in the area feature simple circular or oval single-floored tombs. Since Siret's excavation at the beginning of the 20th century and after G. and V. Leisner's (1943) and P. Bosch Gimper's (1969) comprehensive studies, the Almizaraque site has been recognized as highly ranked in the early copper production in the region. Consequently, this interpretation clearly reflects the importance attributed to east Almería, and also to the gap in understanding of the processes of transformation, consolidation and evolution of the different social formations that took place during the sixth and second millenia BC, and, particularly, understanding when, how, and why this process began.

To answer all these questions Cámalich Massieu and Martín Socas $(1983$; 1986) presented in 1985 a research project on the development of social formations in late Prehistory in the Vera Basin and the valley of the Almanzora River (Fig. 1). It was carried out under the Junta de Andalusia's public convocation for regulating interventions on Archaeological Heritage. In fact, its aim was to analyse the transformation of the area from the beginnings of fishing and agricultural production to the development of social hierarchy in the Bronze Age (Cámalich Massieu et al. 1993).

Consequently, the general and priority aims were:

(1) To carry out a comprehensive study, including all the useful factors for debating its analysis and its general interpretations; and

(2) to determine how these factors take part in the configuration of this historical process.

The project develops from four types of field actions: 1 Study of territory; 2 stratigraphic surveys; 3 Systematic archaeological excavations; and, 4 Rescue interventions.

The development of the project was divided into successive phases, due to the aforementioned aims and its application over a large area. The first phase was focused on the area of the mouth of the Almanzora River, and covers all the area of the Vera Basin (Fig. 1), limited to the south by the Sierra de Cabrera, to the north by the Sierra of Almagrera y Almagro, and to the west by the municipality of Cantoria.

Work has been done on:

(1) Systematic excavation of the settlements of Campos and Zájara (Cuevas de Almanzora). The latter is still under study.

(2) Prospecting with stratigraphic surveys on the site of Cabecicos Negros-El Pajarraco (Vera).

3 Rescue excavations on the sites of Puente de Santa Bárbara (Huércal-Overa), Las Pilas/Huerta Seca (Mojácar), and Cabecicos Negros (Vera).

(4) A study of a large part of the territory of the lowlands and midlands of the Almanzora River - with complements from the previous documentation and the later bibliography in 1985. It has permitted a detailed listing of more than 600 archaeological sites.

Regarding the results, the area of this study maintains an intense occupation dynamics during the different periods of Prehistory, from the middle of the sixth millennium $\mathrm{BC}$ until the end of the second millennium BC. This means, in the traditional scale of this area, the Middle Neolithic until the development

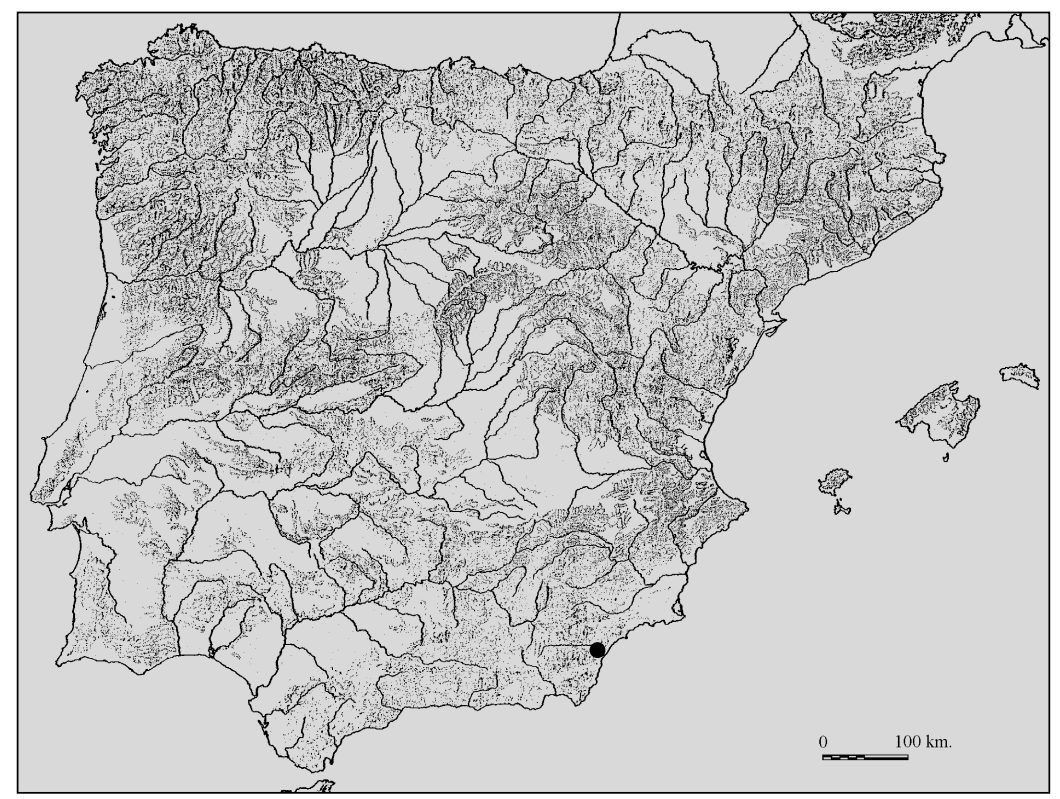

Fig. 1. Area of study. 
of the Final Bronze Age, where its climactic moments would take place starting from the Copper Age. Consequently, the main characteristic of the dynamics of social formations is the continuity of settlement pattern in the territory. The modifications that took place in the development of this pattern can be explained by the search for a location according to the socio-political and economic conditions for each moment. Consequently, internal dynamics become the essential factor in the development of these communities.

Therefore, the oldest evidence in the prehistorical context is associated with the Neolithic, as the chrono-stratigraphic layers of the Andalusian central and eastern regions and radiometric datings from the Cerro Virtud show. However, the principal researchers defend the hypothesis that this context is correlated to the beginning of the process of metallurgical production in the southeast. Its development would have taken place, at least, from the mid sixth millennium until the end of the fifth and the beginning of the fourth millennium $\mathrm{BC}$, in calibrated dates, between $6160 \pm 180 \mathrm{BP}(4120 \mathrm{BC})$ and $5300 \pm 120$ $\mathrm{BP}$ (3710 BC) (Delibes de Castro and Montero 1997; Montero Ruiz and Ruiz Taboada 1996; Ruiz Taboada and Montero Ruiz 1999).

In general, as is typical of other Andalusian areas, they are outdoor settlements of small dimensions. The small residence structures were probably built from perishable materials, evidencing seasonal occupation, also associated with river beds, elevations, or coastal sites and, exceptionally, caves or shelters.

It is necessary to highlight the results obtained in the first of our excavations of the villages of Zajjara (1987 and 1990) and Cabecicos Negros (1991 and 2000) during the initial phase of the Project (Cámalich Massieu and Martín Socas 1999; Goñi Quinteiro et al. 2003).

The present location of Cabecicos Negros (Vera) is $20 \mathrm{~m}$ above sea level, on the left bank of the River Antas, and about $2 \mathrm{~km}$ from its outflow in the Mediterranean. In the Neolithic the site was located on the coast, as the results of the Proyecto Costa (Arteaga and Hoffman 1987) demonstrated. Thus, their immediate environment was a wide bay. It forms part of a group structured with the so-called El Pajarraco, although it is now divided by the Vera-Garrucha road. The two interventions, in 1991 and 2000, at this location were carried out in a special context because it was partially affected by the urban expan- sion plans of the Vera coastal area agricultural works. Consequently, the objectives were, besides elaborating a precise delimitation of the location, the realization of stratigraphic polls in the different sectors because the superficial archaeological survey identified a wide time-span for occupation over a large area.

The results obtained for the oldest period of occupation specify small settlement nuclei distributed on the six hills on the left bank of the Antas River and across the plain, which are a result of recurrent occupation of the same territory. Of the different excavation areas, the northeast hill site stands out because it helped to determine that this was a single occupation layer site. It allowed an analysis of the special topography of the hillside, which has a series of natural steps that could have been used for the grounding of small structures, built with stone and mud walls, with roofs made from vegetation, as the collapsed constructions indicates.

In these ceramic groups (Figs. $2 ; 3.1-4 ; 4.5-17$ ), the most abundant are decorated in different techniques with a wide variety of ornamental motifs. Regarding the impressed ceramics, there is abundant cardial ceramic, as well as specimens obtained from other matrices or with a pointed tool, resulting in very different ornamental motifs that are either isolated or mixed with intertwined and grooved lines, both curved and rectilinear. The relief decorations are made with cords and most have impressions. It is necessary to equally highlight the presence, in some of these decorations, of engobe filled with redcoloured slips (almagra). There are different types of handles, with flattened or solid protuberances, but mainly spout-shaped. With respect to the form and size of these, analysis is limited because there are few complete reconstructions, due to the high degree of fragmentation and erosion. However, in some cases it has been possible to infer narrow borders, and necks of varied dimensions.

Among these ceramic records from Cabecicos Negros, the impressed cardial decorations stand out. This pottery corroborates the hypothesis that the characterisation of the Neolithic in this area correlated with the settlement process in the High Andalusia region and in the Central-Eastern coast. (Cámalich Massieu and Martin Socas 1986). In addition, these were open-air settlements, which again emphasises the importance of this occupation type rather than the traditional view of a preferential cave settlement. 


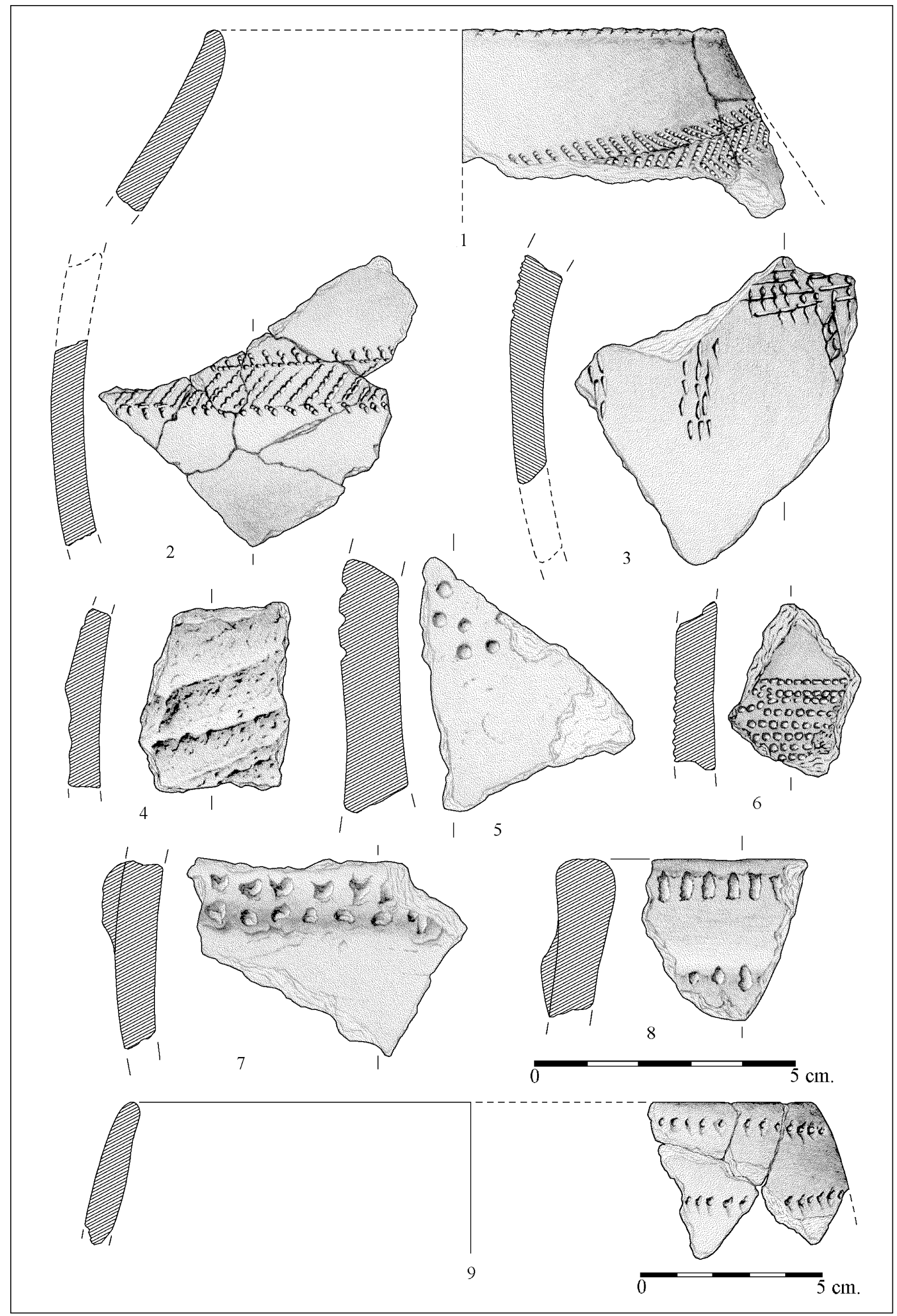

Fig. 2. Pottery. Cabeci cos Negros. 
Indeed, the presence of impressed cardial ceramics is not new in the Andalusian Neolithic, although its proportion in the general ceramic record is not the most abundant, as is the case in the peninsular Levant region, where cardial ceramics characterize the Early Neolithic. On the contrary, in the south of Iberia the cardial ceramics appear in the initial phases of the Andalusian Neolithic, coexisting with other impression types: the use of other matrices, such as the combed, pointed or blunt object decorations, and also those with relief cords, as well as incised and graffiti ceramics, and the characteristic use of almagra, either as a slip or to fill incised or impressed decorations.

Lithic production (Martínez Fernández and Afonso Marrero 1999) forms an important assemblage of more than 1300 pieces, of which almost half are semi-finished products from the manufacturing process, and where a considerable amount of lithic nuclei have been identified. Among these there are abundant flakes from local rock materials and from foraminiferous radiolarian siliceous rocks, whose origin is located in the Vélez region. As already mentioned, flakes are dominant (over 50\% in Cabecicos Negros); therefore, considering that the flakes constitute $38 \%$ of the sub-products, this industry could qualify as a laminar manufacturing type.

The production techniques recorded are the same as those used in other areas of Andalusia, that is to say, by means of pressure on the previously heated nuclei, prismatic flakes are produced. The method may have been either direct or indirect percussion, although this is still not known (Martínez Fernández and Afonso Marrero 1999).

The traceological analysis carried out on the lithic production (Rodríguez Rodríguez 1999), has contributed information on different aspects of the manufacturing process itself and its role in everyday activities. Although a considerable part of the worked lithic material presents post-depositional alterations that hinder its study, a significant number of pieces still exists with use prints that testify to diverse types of activities in the settlement and its surroundings (Goñi Quinteiro et al. 1999) (Fig. 3.516).

The low percentage of lithic tools related to the acquisition of consumption products is outstanding. Only one piece was used as a sickle in cereal harvesting, whilst three geometrics were employed as projectile points, presumably in hunting activities. Meat processing and hide treatment are scarcely represented. The handicraft activities left a large quantity of artefacts, in which the transformation of diverse mineral materials stands out. Indeed, perforators, flakes and thin modified sheets, as well as unmodified flake products were used to perforate, saw, groove, scrape and, possibly, to crack marine shells and rocks of varying hardness, although soft materials such as slate stand out. It is seen that the presence of a significant quantity of personal ornaments elaborated from these same raw materials corroborates the importance that this craft must have had. This work was carried out with two types of tool: some very elaborate, such as the micro-perforators, and others of more expeditious manufacture, such as unmodified or slightly worked flakes and laminar sheets. In this latter group, there were also recycled pieces, as is the case of two micro-laminar nuclei which were used as scrapers. This dichotomy shows that the most complicated part in these production chains was, undoubtedly, the perforation process, which is also the case with the ornaments, many pendants being abandoned during manufacture due to perforation failures.

Leatherwork was also important at this site and, with the exception of leather which was worked when the hide was fresh - supposedly from a recently killed animal - most was done on dry leather that could be stored or brought from another place. However, the transformation of wood or bone has left scarce evidence in the analyzed material.

In this settlement, personal adornments had great relevance. They are mainly small discoid or elongated beads made from shells (Fig. 4.8-14), and a great variety of bracelets (Fig. 4.1-7), with different types, sizes and materials used, including local slate, and marble-like stones from the Almanzora River. We must stress that an important part of this group is in different stages of manufacture, which means that it had reached a very high degree of standardisation. It was the result of a very specialized activity directed towards trading surpluses at regional and interregional levels.

Polished stone tools are not very abundant, and consist of axes, adzes, and chisels, mainly of circular or oval cross-section, with simple bevel sharp ends, and grinding elements, used in food processing.

The bone tools also lack variety and, being mainly perforation implements, such as punches, that could be related to the leather works. 

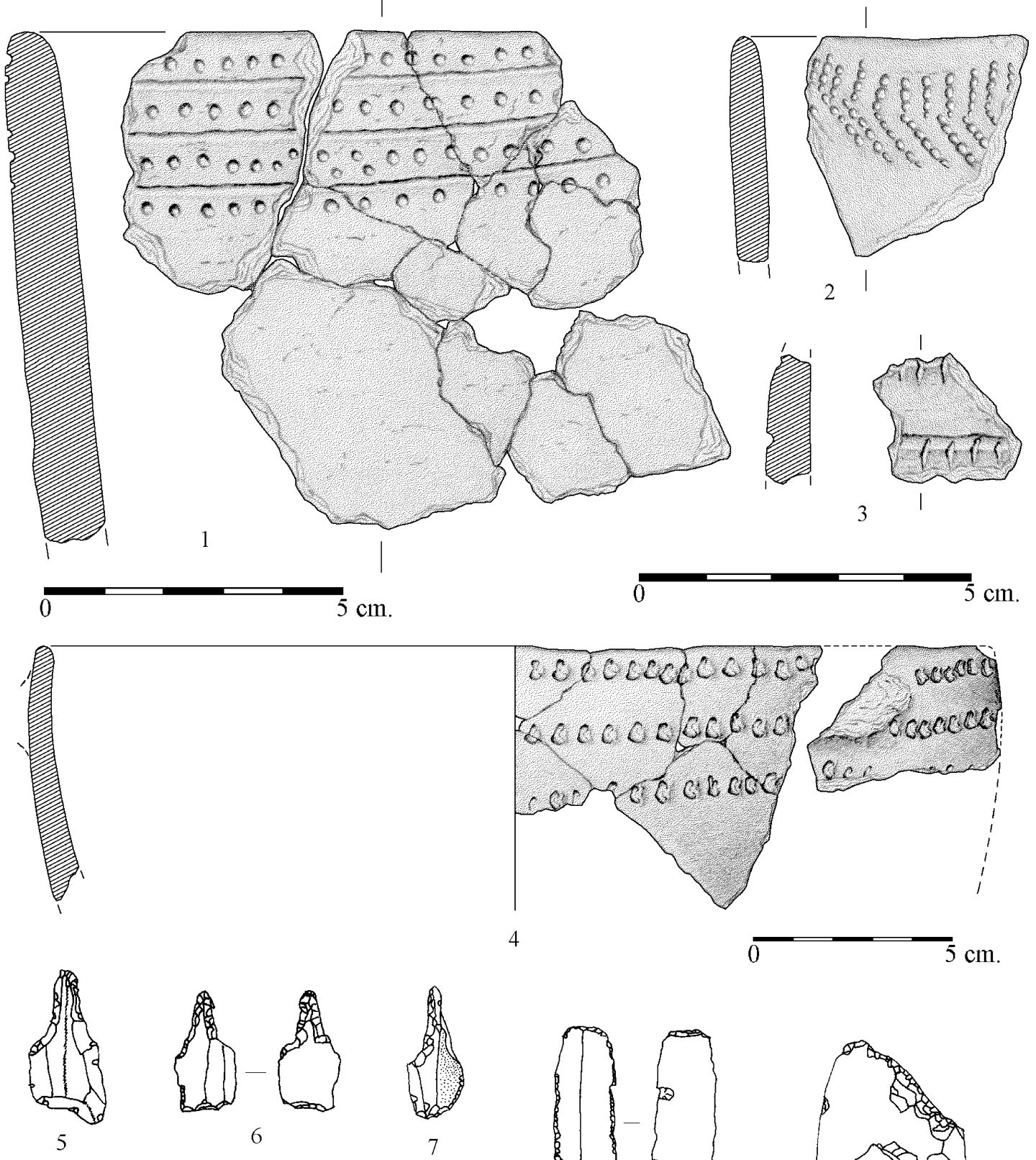

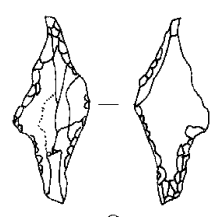

8
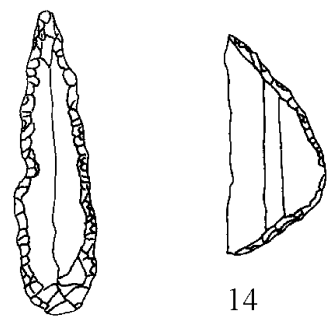

14

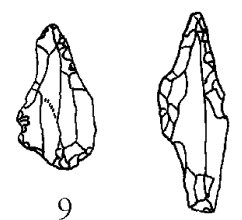

10

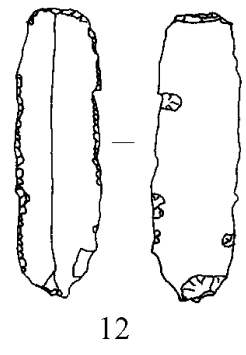

11

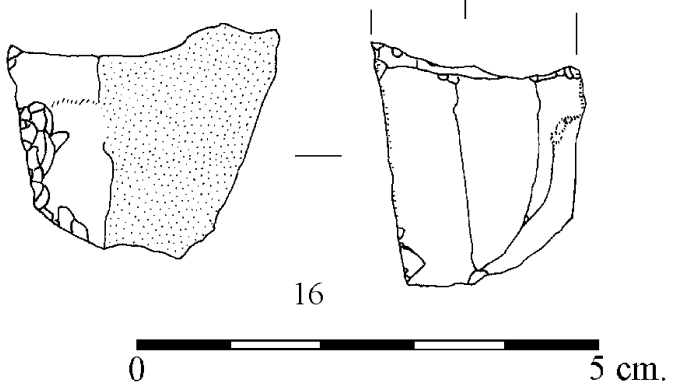

Fig. 3. Pottery and carved lithic productions. Cabecicos Negros. 
Therefore, in the village of Cabecicos Negros certain surplus craft activities were carried out to the detriment of others more related to subsistence. This would imply that the community was integrated within a wider territory, where its inhabitants would be able to subsist, either by means of seasonal movements to exploitable areas, or from an exchange network of local products between communities.

In this context, the recurrent association of the various productions, where the presence of cardial ceramics in Cabecicos Negros should be highlighted, supports the hypothesis of an occupation of the Almerían lowlands since the oldest phases of the Neolithic. This corresponds to findings from other Western Andalusia locations such as the cave of Carigüela (Piñar, Granada), the site of Las Majolicas (Alfacar, Granada), the caves of Malalmuerzo (Moclín, Granada), and Los Murciélagos (Zuheros, Córdoba), or occupation Phase I of the site at Los Castillejos (Montefrío, Granada) (Martín Socas et al.1998). On the other hand, the date proposed for these moments coincides with the last chronologies contributed by Cerro Virtud (Cuevas del Almanzora) that, as already pointed out, date the Neolithic occupation of this village to the second half of the sixth millennium and throughout the fifth millennium BC, calibrated date (Ruiz Taboada and Montero Ruiz 1999).

Consequently, the traditional interpretation of the beginnings of production in this area, in which the first cohesive population structure would correspond to the Late Neolithic and would be in some way associated with the Cultura of Almería (Fernández Miranda et al. 1993), cannot be accepted.

Regarding the site of Zajara, located on an elevated plateau at the convergence of the River Almanzora and the Alifraga ravine, at $111 \mathrm{~m}$. above sea level, its study has added fundamental information with respect to the general aims of the project. Apart from the clearly particular characteristics of the Copper Age settlements, the presence of a Neolithic occupation could be inferred, thanks to information from materials deposited in the National Archaeological Museum which came from one of the caves excavated by L. Siret, as well as those on the higher sector of the plateau.

Indeed, this possible occupation, prior to the development of the initial phases of the metallurgy, is the one that we are interested in highlighting in this work, was documented during the 1990 excavation campaign. There was a pit, with a large ceramic re- ceptacle (approximate capacity 38 litres) inside, located in the central area of the plateau. The pot has been identified as a water container, with an ellipsoid body, a slightly conical bottom, three flattened handles with double perforations distributed regularly around the body, and a cylindrical neck. Its mouth was level with the floor and it had been covered by a fragment corresponding to the paunch of another ware, of equally large dimensions, that had impressed cords as a relief decoration. Inside the pot, there was another receptacle of smaller dimensions (approximate capacity, 1 litre). This group, from its technological, formal and ornamental characteristics is indicative of the Neolithic occupation of the site whose intensity cannot yet be evaluated, since work at this location is continuing.

A series of large excavated structures stand out and, given their construction and morphological features, as well as to the identification inside the only partially registered one of a domestic combustion structure, they were shelters with very similar characteristics to those documented in various sites of the valley of the Guadalquivir, in the final stages of the fourth and beginnings of the third millennia BC. Such is the case, among others, of the Polideportivo de Martos (Jaén) (Cámara Serrano and Lizcano Prestel 1996; Lizcano Prestel 1999). Here, we must point out that almost 150 pits at the El Garcél settlement described in P. Flores' field notebooks could be linked to this function.

In consequence, the current documentation available from the structures and the identified evidence allow us to date the beginnings of the occupation of Zájara to the Middle and Late Neolithic.

Taking into account the data we have for the low valley area of the Almanzora River and Vera Basin, the Neolithic settlements of Los Cabecicos Negros, as well as the village of Zájara can not be isolated phenomena. They are indeed clearly correlated both with the general characteristics of the settlement type and with the different groups of materials also observed in other well-known sites in the area (Fig. 5). Consequently, we can indicate that there were two fundamental types of settlement located in elevated sites. The first is recognized as a small hill settlement, close to streams, river mouths and ancient coastlines (Arteaga and Hoffman 1987; Schubart et al. 1988). This type of settlement could be represented by villages like Almizaraque on the Almanzora River, Cabecicos, Negros-Pajarraco in the Antas, and La Isleta, or the Loma del Campo in the basin of 

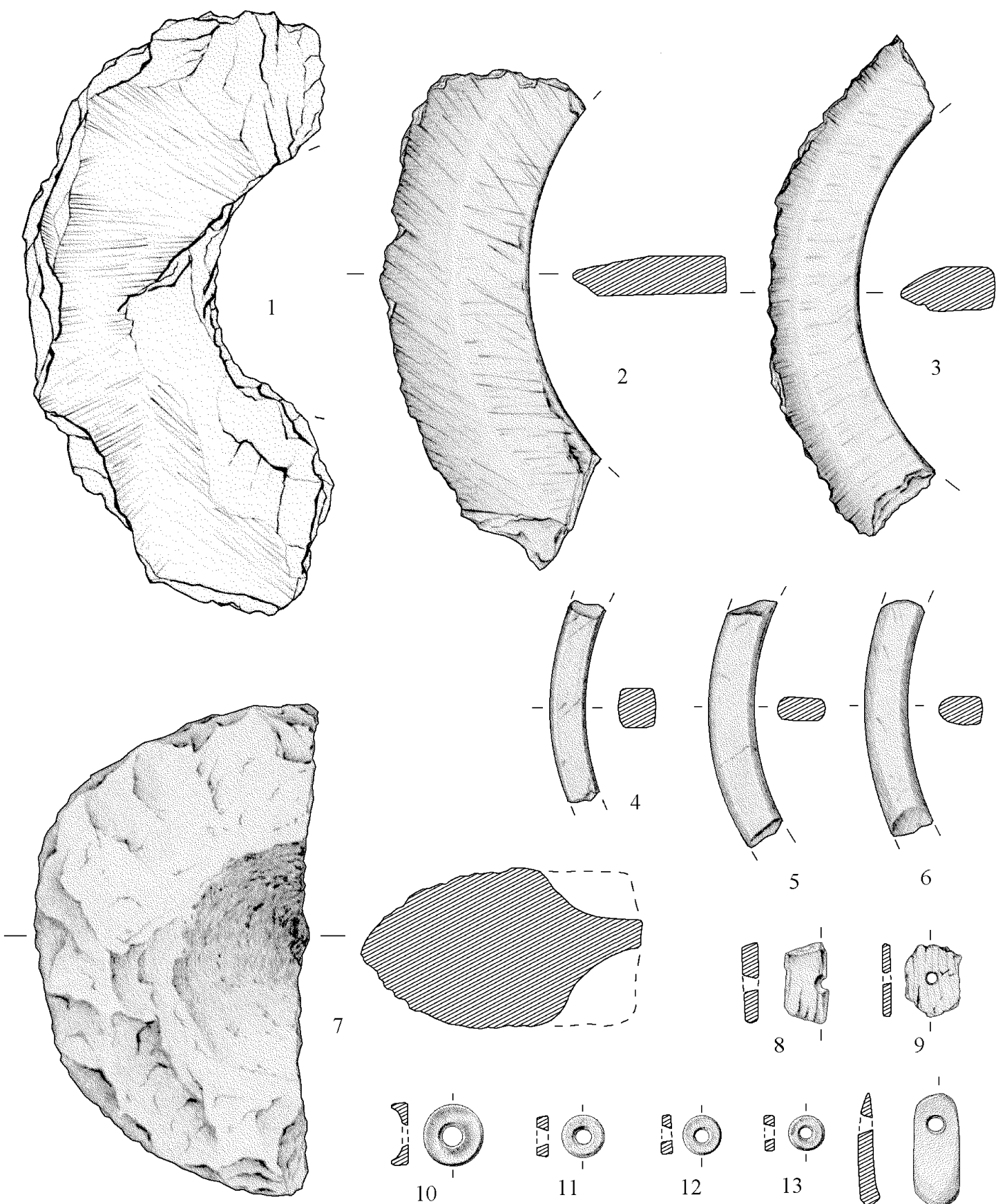

5

6
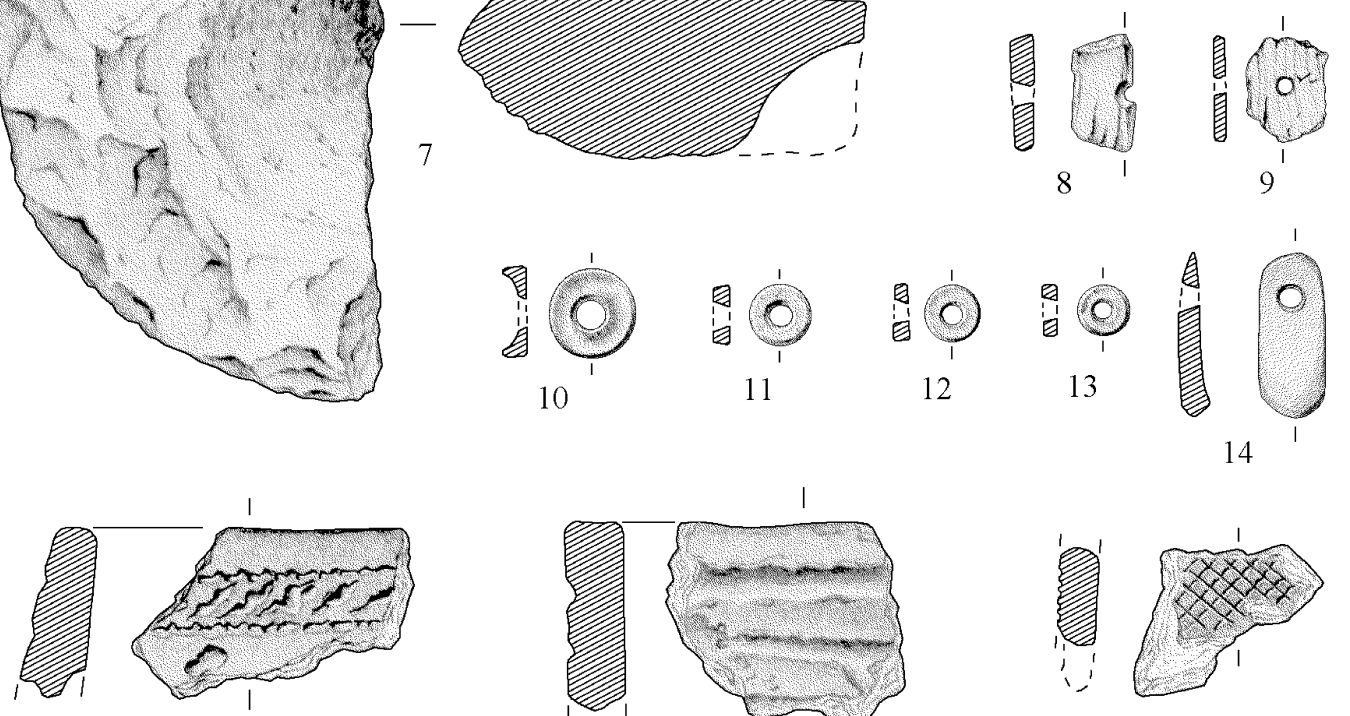

15
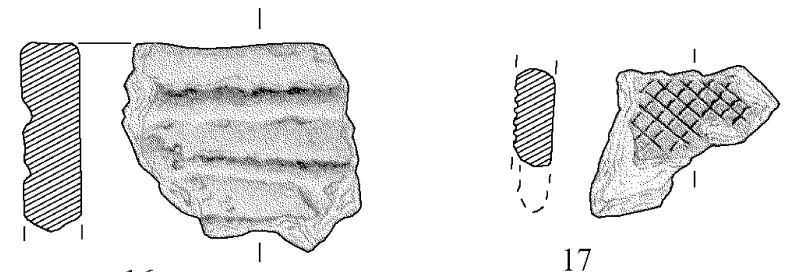

16

$5 \mathrm{~cm}$

Fig. 4. Lithic personal ornaments and pottery products. Cabecicos Negros. 
the Aguas River (Fig. 5. Nos. 147, 155 and 19 (respectively), 58, 52). At the same time, there was a second type of settlement on elevated sites, such as single hill-tops which dominated basal areas, whose occupation in some cases continued during the Late Neolithic. Some examples of this type of habitat are: El Peñascal, Cerro Virtud, Zájara, Raja Ortega, Cuartillas, Moro Manco, Cerro Guevara, Cerro del Cortijo de Gatas and, probably Cerro María and Cerro del Espíritu Santo (Fig. 5. Nos. 347, 146, 144, 66, 42, 26, 62, 34, 7 and 163). After this period, an intense period of Late Roman and Hispanic-Muslim occupation can be identified. The main characteristic was the interrelationship between these different and separated settlements by visual oversight of the whole basin, which meant considerable control over this extensive area.

In the high and middle basins of the Almanzora River, the open-air settlements are situated in the mountain areas of the Sierras de Filabres or of Las Estancias, such as La Cerrá, Macael or Partaloa. Others, like El Palo or El Castillico de Cobdar, are cave settlements (Fig. 5. Nos. 371, 620, 136). All of them, including Los Cabecicos Negros, have a very defined and representative group of materials belonging to the Neolithic of southern Iberia. This evidence coincides with results obtained in settlements with wide stratigraphic layers, such as the caves of Carigüela (Granada), Nerja (Málaga), El Toro (Málaga), or Los Murciélagos (Córdoba) (Martín Socas et al. 1998).

In relation to what has been said, the socio-economic formation was based on the exploitation of the environment through itinerant occupation of territory variable size, which depended on the communities and the seasons. Consequently, this seasonality or periodicity allowed for the acquisition of various resources through a strong tendency to move and to set up seasonal settlements. Therefore, these were small, and aimed at obtaining subsistence goods as well as towards the transformation/exploitation of raw materials for the production of handicraft surpluses which were traded with other communities in the same area or from other regions. This would largely explain why the archaeological evidence indicates a large number of manufacturing crafts from local raw materials. It could also explain, in the case of Cabecicos Negros, the presence of a single tool for the harvesting of cereals. It is also true that we chose

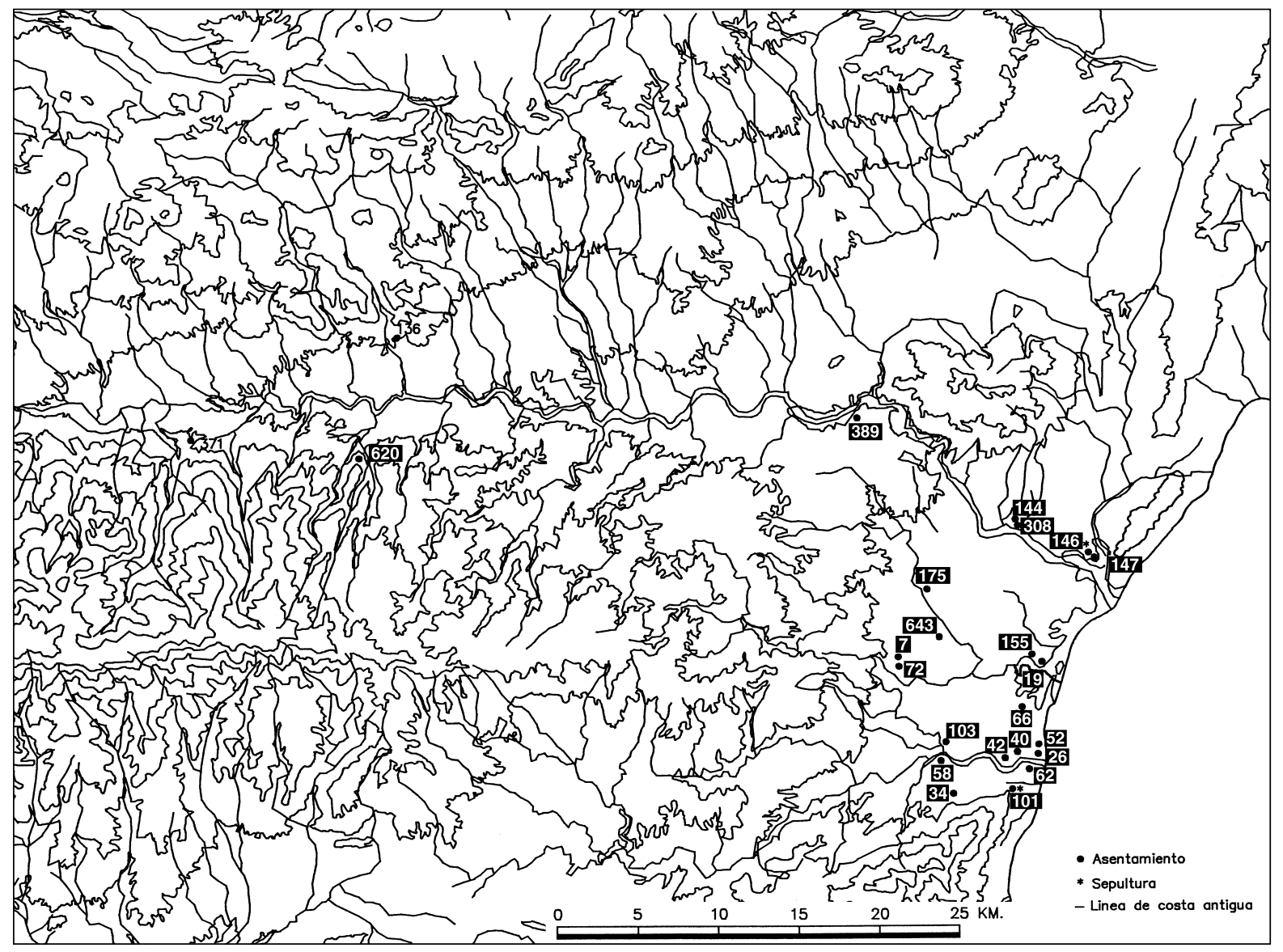

Fig. 5. Map of Middle Neolithic sites. 
the agricultural factor as the priority element in the hypothesis to understand the first Neolithic occupation (Fernández Miranda et al. 1993), as well as its being the cause of the transformation process towards the complexity of later social formations in this large area. In this context, we would have to use the terms "agricultural colonisation or intensification". A good example is the Neolithic village at the Polideportivo of Martos (Jaén) ${ }^{1}$.

Therefore, the traditional importance assigned to the agricultural variable in these communities does not seem to correspond to all the findings, which, in turn, has meant that its systematic and mechanical application has generated in some recent research work a strong rejection of the evidence of such an old settlement in the Alto de Almanzora. The weight of this reasoning is based on strong natural or anthropic erosion that would have affected the elevated areas chosen by these communities (Román Díaz et al. 1996; Román Díaz and Martínez Padilla 1999). This assumes a certain occupation pattern based on a reduction in farming.

Nevertheless, there must be initiated/completed further studies on these various activities in order to gain knowledge on the development of these social formations. Moreover, both the existent relationship between them and the dynamics of the trade exchanges and how these would influence the transformation processes, especially during the Final Neolithic, could be identified.

Gradually, it is observed how the aggregation and settlement processes were established at this period through the appearance of excavated living and storage structures, the silos, increasing the stability of occupation, and the exploitation of the territory. Parallel to the settlement process and, consequently, that of land appropriation, the normalised independent burial zones become reinforced as a result of the wider and deeper structuring and organisation process of these social formations.

The final phase of the Neolithic, which in many aspects is undistinguished from what has become known as an Early Copper Age and determined by the presence of metallurgical evidence, consolidates this mechanism of doubling of settlements - that is, neighbouring sites were closely interconnected - and, the demographic pattern as seen in the previous phases (Fig. 6). Thus, together with the continuity of some of the previous occupational nuclei such as Cerro María, Cuartillas, Loma del Campo, Zájara, Cerro Virtud, Almizaraque, and Cueva de Zájara, there were some settlements on elevated plateaux over the fluvial bed (Fig. 6. Nos. 7, 42, 52, 144, 146, 147 and 308). These sites had more useful horizontal surface areas for the construction of semiexcavated rooms that, on occasion, had a central post, as well as storage structures, silos, which probably had different uses, as could have been the case with water containers. The aforementioned villages, as well as the Tres Cabezos, La Torrecica-Cortijo Soler, El Arteal, and those already mentioned at El Garcel, Zájara, and Las Pilas/Huerta Seca, in the Vera Basin - which coexisted with high dominant sites - and the Muela del Ajo or Cañada del Herrero - in the middle and high basins of the Almanzora are good examples of these dynamics (Fig. 6. Nos. 159, 298, 100, 179, 595 and 596, 372 and 402).

Consequently, larger communities were established in diverse environments, spanning various biotopes, and with a pattern that implies a strong relationship between them, possibly depending on a work force that integrated into larger units. At the same time, a process of social dissymmetry and of a differentiated appropriation of subsistence or non-subsistence goods developed. Even though the smallest groups were self-sufficient in order to cover basic necessities, this cannot be considered a general rule, because they could not have been so in all aspects: firstly, obtaining certain primary resources; secondly, the possibility of guaranteeing the whole production cycle of animal and agricultural products in the event of failure or accident; and thirdly, the fact that they would have been too far from the main route connections which would facilitate access to the valley, where the main sites were located. In consequence, the dynamics of power structures would have consolidated in the Copper Age.

At present, it is difficult to obtain a correct chronological and evolutionary sequence of the Copper Age in the region, although the research in the last few years has contributed very outstanding data. The hypothesis is that, with the beginning of settlement and the political delimitation of the territory - in parcels smaller than those inferred for the previous

1 "...demonstrates that the settlement nuclearisation process at the beginning of the third millenium was not unilineal and could be explained by other models in which agriculture is not the main factor in changes in the relationship between production and social formations" (Cámara Serrano and Lizcano Prestel 1996). 


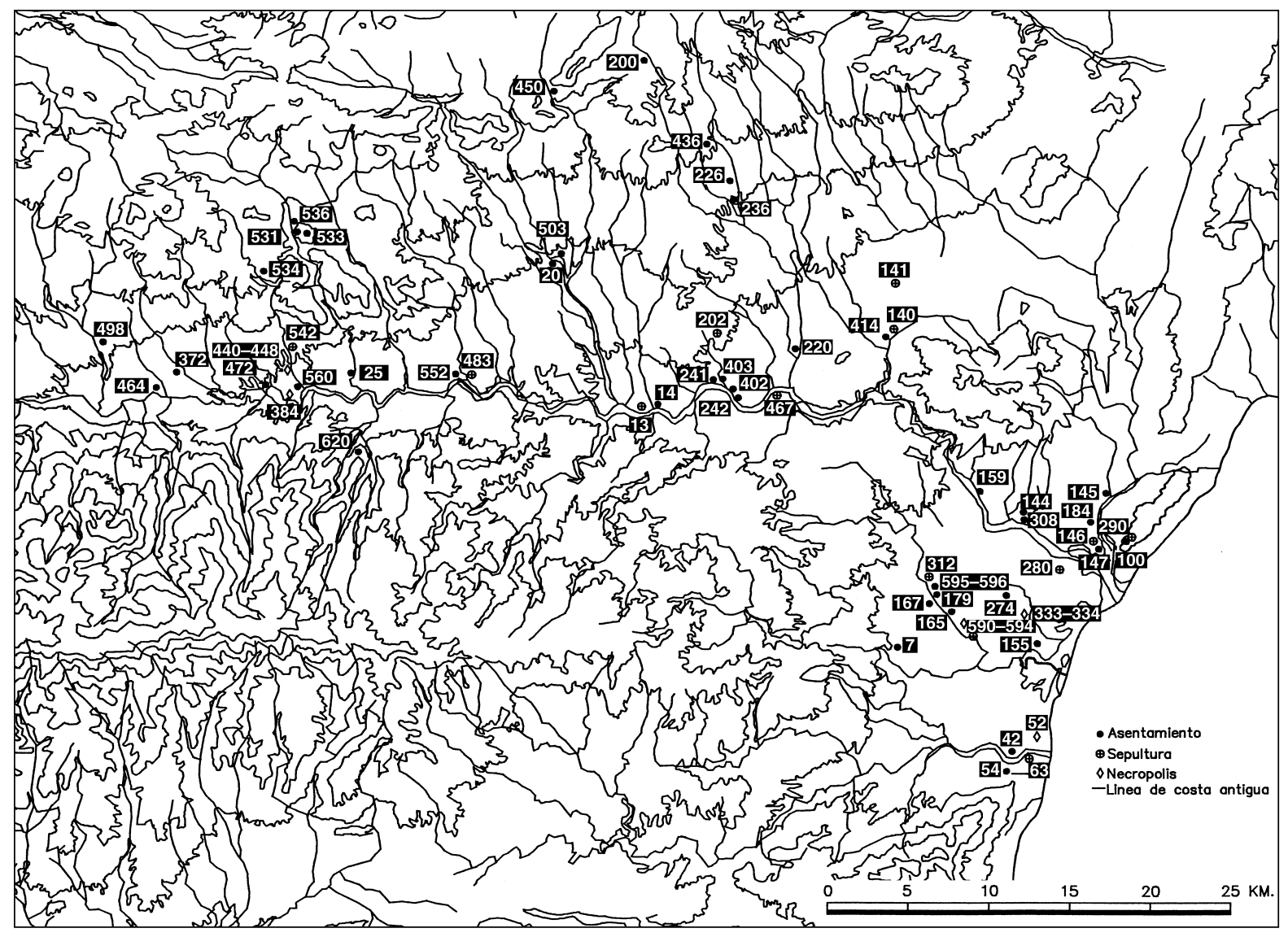

Fig. 6. Map of Late Neolithic/ Early Copper Age sites.

phase - there would be continuity in the exploitation pattern. However, it seems that now the river courses of the Almanzora, Antas, and Aguas, would have become the axes of new settlement patterns. These were characterized by larger settlements, with funerary zones of concentrated burial structures, which symbolise centralisation and land ownership, as well as by a series of interdependent and complementary villages. This model would be represented in the Vera Basin by LasPilas/Huerta Seca site which, with the village of Cuartillas, has the associated sepulchres of the Las Lomas del Campo and of El Cerro de la Mata, located at the outlet of the River Aguas (Fig. 6. Nos. 54, 42, 52, 63). In the area of Antas, the pattern would be the group of El Garcel, with which the villages of Las Ramiras and Alto de la Cañada del Cura are related, together with the sepultures of the Lomo de la Rutilla and the La Pernera-1 (Fig. 6. Nos. 179, 595 and 596, 165, 167, 590-594, 312). In the lower basin and outlet of the River Almanzora, Almizaraque is the most important site, with which the site and the burials sites of Cerro Virtud, the village and the cave of Zajara, Tres Cabezos, La Torrecica-Cortijo Soler, Los Sifones, and the tomb of El Arteal are associated (Fig. 6. Nos. 147, 146, 144 and 308, 159, 184, 145, 290)
In the middle and high river basin there would have been, on the one hand, the Llano de los Pedregales/ Casablanca, with which the sepulchre of the Cabezo de la Copa is associated, as well as the villages of $\mathrm{La}$ Quinta, Terrera Alcaina and El Llano de las Ánimas3 , that control access from the high areas of the Sierra de Las Estancias toward this sector of the Valley (Fig. 6. Nos. 14, 13, 236, 20, 503). On the other hand, there was the Churuletas group, which included the village of the Cerro de los Navíos, and the associated necropolis of El Llano de Turuletes/Churuletas, of Llano de la Lámpara/Loma de la Estación, and of Loma de la Jocalla/Cortijo Jocalla (Fig. 6. Nos. 560, 440-448, 420-421, 424-425).

These settlement and centralisation processes in the study area could be partly related to the development of new agricultural and pastoral techniques, which tended towards the restriction of the movement of large livestock, and to the practice of transhumance of ovicaprine flocks. R. Buxó (1997) in his study of the cave de El Toro (Málaga) points out that the differences in the agricultural activities inferred from the carpological remains for the Middle and Late Neolithic indicate an evolution from a primitive agriculture to a more evolved one. This is shown, in 
the higher layers of the Late Neolithic in the southeastern region, by the change of frequencies of naked barley and bean that seem to point out a pattern of alternating exploitation of the two cultivated species. This agricultural model, observable in Toro from the Late Neolithic, is based on the use of cereals and leguminous crops, which implies that the cultivable land was stable (Martín Socas et al. 1999; 2004). This fact, together with other factors such as demography, production and organization during the end of the Late Neolithic/Early Copper Age, consolidated a system of dependent relationships between social groups, which would distinguish the political connections of the Copper Age in the area.
Therefore, it can be said that the process of development was long and that this process of change was characterized by a convergence of multiple factors of different nature. The acquisition and transformation of different products not exclusively used for agricultural production acquire an important role in this change. We have to admit that data on this whole process is incomplete, although we must not forget that these studies - particularly the significant excavation at Las Pilas/Huerta Seca - have shed more light on the final periods of the Neolithic and its connection with the beginnings and the development of the Copper Age (Cámalich Massieu and Martín Socas 1999).

\section{REFERENCES}

ARTEAGA 0. and HOFFMAN G. 1987. Investigaciones geológicas y arqueológicas sobre los cambios de la línea costera en el litoral de la Andalucía mediterránea. Anuario Arqueológico de Andalucía 1986 II: 194-195.

BOSCH GIMPERA P. 1932. Etnología de la Península Ibérica. Barcelona.

1944. El poblamiento antiguo y la formación de los pueblos de España. México.

1965. La significación del Neolítico circunmediterráneo. Pyrenae 1: 21-30.

1969. La Cultura de Almería. Pyrenae 5: 47-93.

BUXÓ R. 1997. Arqueología de las Plantas. Barcelona.

CÁMALICH MASSIEU Mํ. D. 1983. La cerámica eneolítica no campaniforme de Andalucía Sudoriental. Anuario 81-82 de la Universidad de La Laguna. Sección de Derecho, Geografía e Historia I: 133217.

CÁMALICH MASSIEU M‥ D. and MARTÍN SOCAS D. (Drs.) 1999. El Territorio almeriense desde los inicios de la producción hasta fines de la antigüedad. Un modelo: La Depresión de Vera y Cuenca del río Almanzora. Sevilla.
CÁMALICH MASSIEU Mํㅗ. D., MARTÍN SOCAS D., MEDEROS MARTÍN A., GONZÁLEZ QUINTERO P., DÍAZ CANTON A. and LÓPEZ SALMERÓN J. J. 1993. La Edad del Cobre en la Cuenca del Bajo Almanzora. Investigaciones Arqueológicas en Andalucía (19851992). Proyectos: 317-327.

CÁMARA SERRANO J. A. and LIZCANO PRESTEL R. 1996. Ritual y sedentarización en el yacimiento del Polideportivo de Martos (Jaén). I Congrés del Neolí tic a la Península Ibèrica, Gavá-Bellaterra, 1995. Rubricatum 1-2: 313-322.

CHAPMAN R. 1978. The evidence for prehistoric water control in south-east Spain. Journal of Arid Environments 1: 261-274.

1984. Early metallurgy in Iberia and the west Mediterranean: innovation, adoption and production. In W. H. Waldren, R. W. Chapman, J. Lewthwaite, R. C. Kennard (eds.), The Deya Conference of Prehistory Early settlement in the western Mediterranean Island and their Peripherical Areas, British Archaeological Reports, International Series 229: 139-165.

1991. La formación de las sociedades complejas. El Sureste de la península en el marco del Mediterráneo occidental. Barcelona.

DELIBES DE CASTRO G. and MONTERO RUIZ I. 1997. Els inicis de la metal.lúrgia a la península Ibèrica. 
Tranferència de tecnologia o descobriment autònom? Cota Zero 13: 19-28.

FERNÁNDEZ MIRANDA M., FERNÁNDEZ-POSSE Maㅡ. D., GILMAN A. and MARTÍN C. 1993. El sustrato Neolítico en la Cuenca de Vera (Almería). Trabajos de Prehistoria 50: 57-85.

GILMAN A. and THORNES J. B. 1985. Land-Use and Prehistory in South-East Spain. London.

GOÑI QUINTEIRO A., RODRÍGUEZ RODRÍGUEZ A., CÁMALICH MASSIEU Mํ. D. MARTÍN SOCAS D. and FRANCISCO ORTEGA I. 1999. La tecnología de los elementos de adorno personal en materias minerales durante el Neolítico Medio. El ejemplo de Cabecicos Negros (Almería). II Congrés del Neolític a la Península Ibèrica. (Valencia 1999), Saguntvm-Pla, Extra 2: 163-170.

GOÑI QUINTEIRO A., CHÁVEZ ÁLVAREZ E., CÁMALICH MASSIEU M $\stackrel{a}{a}$. D., MARTÍN SOCAS D. and GONZÁLEZ QUINTERO P. 2003. Intervención arqueológica de urgencia en el poblado de Cabecicos Negros (Vera, Almería). Informe preliminar. Anuario Arqueológico de Andalucía (2000) 1: 73-87.

LEISNER G. and V. 1943. Die Megalithgräber der Iberischen Halbinsel: Der Süden. Berlín.

LIZCANO PRESTEL R. 1999. El Polideportivo de Martos (Jaén): Un yacimiento neolítico del IV milenio a.C. Córdoba.

MARTÍN SOCAS D. and CÁMALICH MASSIEU Mํ‥ D. 1986. Las excavaciones en el poblado de Campos (Cuevas del Almanzora, Almería) y su problemática. Homenaje a Luís Siret (1934-1984): 178-191.

MARTÍN SOCAS D., CÁMALICH MASSIEU Mํㅗ․ D. and GONZÁLEZ QUINTERO P. 1998. Le Néolithique dans l'Andalusie (Espagne). In M. Otte (ed.), Atlas $d u$ NeOlithique Europeen. L'Europe occidentale, Vol. 2B: 871-933.

MARTÍN SOCAS D., BUXÓ CAPDEVILA R., CÁMALICH MASSIEU M‥ D. and GOÑI QUINTEIRO A. 1999. Estrategias subsistenciales en Andalucía Oriental durante el Neolítico. II Congrés del Neolític a la Peninsula Ibèrica. (Valencia 1999), Saguntvm-Pla, Extra 2: 25-30.

MARTÍNEZ FERNÁNDEZ G. and AFONSO MARRERO J. 1999. Producción lítica tallada del poblado de Cabe- cicos Negros. In Mํ. D. Camalich Massieu and D. Martín Socas (Drts.), El Territorio almeriense desde los inicios de la producción hasta fines de la antigüedad. Un modelo: La Depresión de Vera y Cuenca del río Almanzora: 222-225.

MONTERO RUIZ I. and RUIZ TABOADA A. 1996. Enterramiento Colectivo y metalurgia en el yacimiento Neolítico de Cerro Virtud (Cuevas de Almanzora, Almería). Trabajos de Prehistoria 53-2: 55-75.

PANTALEON CANO J., ROURE J. M., YLL R. and PÉREZOBIOL R. 1996. Dinámica del paisaje vegetal durante el Neolítico en la vertiente Mediterránea de la Península Ibérica e Islas Baleares. I Congrés del Neolític a la Península Ibèrica, (Gavá-Bellaterra, 1995). Rubricatum 1-2: 29-34.

RODRÍGUEZ ARIZA Mํ. 0. 1992. Las relaciones hombre-vegetación en el sureste de la Península Ibérica durante las edades del Cobre y Bronce a partir del análisis antracológico de siete yacimientos arqueológicos. Doctoral microcard thesis. University of Granada. Granada.

1996. Análisis antracológicos de yacimientos neolíticos de Andalucía. I Congrés del Neolític a la Península Ibèrica, (Gavà-Bellatera 1995). Rubricatum 1-1: 73-83.

RODRÍGUEZ RODRÍGUEZ A. C.1999. Análisis Funcional del Instrumental Lítico Tallado del Poblado de Cabecicos Negros. In Mㄹ. D. Camalich Massieu and D. Martín Socas (Drts.), El Territorio almeriense desde los inicios de la producción hasta fines de la antigüedad. Un modelo: La Depresión de Vera y Cuenca del río Almanzora: 225-235.

ROMÁN DÍAZ Mํa P. P. and MARTÍNEZ PADILLA C. 1999. Primeras aldeas con almacenamiento en el Sureste de la Península Ibérica. II Congrés del Neolític a la Península Ibèrica, (Valencia 1999). Saguntvm-Pla, Extra 2: 199-206.

ROMÁN DIAZ Mํㅡ. P., MARTÍNEZ PADILLA C., SÁNCHEZ QUIRANTES L., PÉREZ CARPENA A. D. and CASSINELLO ROLDÁN S. 1996. El Neolítico en la Cuenca Alta del río Almanzora (Almería). Una revisión crítica. I Congrés del Neolític a la Península Ibèrica,(Gavá-Bellaterra, 1995). Rubricatum 1-2: 613-618.

RUIZ TABOADA A. and MONTERO I. 1999. Ocupaciones neolíticas en Cerro Virtud: Estratigrafía y data- 
ciones. II Congrés del Neolític a la Península Ibèrica, (Valencia 1999). Saguntvm-Pla, Extra 2: 207212.

SCHUBART H., ARTEAGA 0. and KUNST M. 1988. Investigación geológico-arqueológica sobre la antigua línea de costa en Andalucía. Campaña 1988. Anuario Arqueológico de Andalucía (1988) II: 185-189.

WALKER M. J. 1985. El Prado and the southeastern Spanish Chalcolithic. Research Reports of the National Geographic Society 20: 800-803.
1986. Society and hábitat in Neolithic and Early Bronze Age south-east Spain. In A. Fleming (org.), The Neolithic of Europe. The World Archaeological Congress. Southampton.

YLL E. I., PÉREZ OBIOL R., PANTALEON CANO J. and ROURE J. M. 1995. Dinámica del Paisaje vegetal en la vertiente mediterránea de la Península Ibérica e Islas Baleares desde el Tardiglaciar hasta el presente. In T. Aleixandre T. Campos and A. Pérez-González (eds.), Reconstrucción de Paleoambientes y Cambios Climáticos durante el Cuaternario. IX Reunión Nacional sobre el Cuaternario: 319-328. 